\title{
Postharvest Losses of Fruits and Vegetables Marketed in Seven Municipalities of the East Mesorregion, Maranhão, Brazil
}

\author{
Antonio Gabriel da Costa Ferreira \\ Engenheiro Agrônomo na Fazenda Typuana; Brejo, Maranhão, Brasil. \\ E-mail: agcf09@gmail.com
}

Lusiane de Sousa Ferreira (Corresponding Author)

Engenheira Agrônoma, Caxias, Maranhão, Brasil. E-mail: lusianesf@ hotmail.com

Francisco Gilvan Borges Ferreira Freitas Júnior

Discente do Curso de Agronomia, Universidade Federal do Maranhão, Chapadinha, Maranhão, Brasil. E-mail: gilvanjr582@gmail.com

\section{Marina Pacheco Santos}

Discente do Curso de Agronomia, Universidade Federal do Maranhão, Chapadinha, Maranhão, Brasil. E-mail: pachecos1998@gmail.com

\section{Marcelo de Sousa da Silva}

Discente do Curso de Agronomia, Universidade Federal do Maranhão, Chapadinha, Maranhão, Brasil. E-mail: marcelosousamj@hotmail.com

\section{Francisco Ivo dos Santos Aguiar}

Discente do Curso de Agronomia, Universidade Federal do Maranhão, Chapadinha, Maranhão, Brasil. E-mail: ivinhoaguiar@gmail.com 
Tiago Vieira da Costa

Discente do Curso de Agronomia, Universidade Federal do Maranhão, Chapadinha,

Maranhão, Brasil. E-mail: tiagosly@ hotmail.com

Edmilson Igor Bernardo Almeida

Membro Permanente do Programa de Pós-Graduação em Ciências Ambientais, Centro de Ciências Agrárias e Ambientais, Universidade Federal do Maranhão, Chapadinha, Maranhão.

E-mail: edmilson_i@hotmail.com

\title{
Washington da Silva Sousa
}

Professor do Curso de Engenharia Agrícola, Centro de Ciências Agrárias e Ambientais, Universidade Federal do Maranhão, Chapadinha, Maranhão. E-mail: wssousa@gmail.com

\section{José Roberto Brito Freitas}

Professor do Curso de Agronomia, Centro de Ciências Agrárias e Ambientais, Universidade Federal do Maranhão, Chapadinha, Maranhão. E-mail: joserobertobritofreitas@yahoo.com.br

Received: Dec. 23, 2019

doi:10.5296/jas.v8i3.16098
Accepted: Feb. 11, 2020

Published: Mar. 24, 2020

URL: https://doi.org/10.5296/jas.v8i3.16098

\begin{abstract}
The production of fruits and vegetables is listed as one of the most relevant activities in brazilian agricultural conjuncture. However, the amount of losses occurring along the production chain is alarming, especially in the postharvest stage. Thus, it was aimed to conduct a survey of postharvest losses and characterize the scenario of commercialization of fresh produce in the retail market of seven cities in the east of Maranhão state. This work was carried out through direct interviews with 145 traders. The questionnaire with objective questions that covered socioeconomic aspects, handling, flow, conditioning, storage, marketing, and postharvest losses was applied to them. It was found that the traders had little schooling (92\% of traders do not have a high school level) and lack adequate technical knowledge of produce, management, and marketing of fruit and vegetable produce. The traded vegetables are sourced from Piauí, Bahia and Ceará, and drained through canvas-covered trucks $(86 \%)$. The three vegetables with the highest loss estimates are bell pepper $(16.42 \pm 2.21 \%)$, lettuce $(11.79 \pm 0.42)$ and tomato $(11.38 \pm 0.19 \%)$. Though, for fruits, it highlights plum $(35.65 \pm 1.34 \%)$, papaya $(17.93 \pm 3.79 \%)$ and guava $(15.63 \pm 2.79 \%)$.
\end{abstract}


Among the causes, those of physiological order was the most impacting. The largest losses of vegetables occurred in Coelho Neto (17.78\%), Timon (13.46\%) and Brejo (10.73\%) cities. Regarding fruits, the order was Coelho Neto (11.48\%), Brejo (11.27\%) and Timon (10.84\%). There is a need for better training and awareness of traders regarding the adoption of good post-harvest practices and proper management of the commercial activity, as a way to increase the profitability of this activity, which on average is equivalent to two minimum wages per month.

Keywords: origin, physiological losses, socioeconomic, training, traders

\section{Introduction}

Foods play an important role in promoting and maintaining health. An individual's dietary pattern can define their health, growth, and development during their lifetime (Hoek, 2017). Fruits and vegetables are important sources of micronutrients, fibers and other components with functional properties. They are foods with low energy density, that is, with few calories in relation to the volume of food consumed, which contributes to maintaining healthy body weight (Jaime, 2009).

In Brazil, fruit and vegetable agribusiness enables the creation of numerous jobs, especially in the primary sector, due to the high demand for labor from planting to marketing (Sousa et al., 2018). However, according to Cenci (2006) and Guerra et al. (2017), high perishability makes difficult the marketing of fruits and vegetables.

In recent years, has been seen a paradox between the increased productivity of main crops and hunger. Unfortunately, with records around the world, due to inadequate food supply and poor access to efficient postharvest food conservation techniques such as fruits and vegetables, especially in developing countries (Durigan, 2013; Neves, 2016).

According to Neves (2016), Brazil loses $30 \%$ of the total amount of fruit and vegetables produced. By definition, the postharvest loss is characterized by not directing food to consumption due to mechanical, pathogenic or physiological injuries that alter its physical, chemical, microbiological or organoleptic properties (Silva, 2017).

According to a horticultural diagnosis made by SEBRAE (2009), Maranhão could be self-sufficient in the production of most vegetables consumed by its population, as well as generate surpluses to market in other states. Though, Tomm et al. (2018) reported that in six cities of the Chapadinha Microregion (MA), the largest source of fruit and vegetable (89\%) came from neighboring states, such as Ceará. Which enhances the susceptibility to postharvest losses, reduction of final quality and adoption of higher final marketing prices.

Surveys on postharvest losses and the characterization of the commercialization scenario in the fruit and vegetables retail markets in Maranhão are scarce. Although they could assist in the training of traders regarding the adoption of efficient postharvest and management practices, as well as alarming entrepreneurs or the public sector about the need for investments in the fruit and vegetable sector in this state (Silva et al., 2018).

Given the above, the aim was to carry out a survey of postharvest losses and characterize the 
scenario of marketing of produce in the retail market of seven municipalities in the eastern Maranhense mesoregion.

\section{Material and Methods}

The survey was carried out from August 2017 to June 2018, in 145 fruits and vegetables establishments, located in the municipalities of Aldeias Altas (-43.377 W, -4.503 S), Brejo (-42.801 W, -3.685 S), Caxias (-43.202 W, -4.870 S), Grandson Rabbit (-43.102 W, -4.261 S), Duke Bacellar (-43.002 W, -4.103 S), St. John of the Soter, (-43.744 W, -5.012 S), and Timon (MA) $(-42.927 \mathrm{~W},-5.196 \mathrm{~S})$, which have a population of $26.387,36.139,49.246,164.224$, 11.296, 18.438 and 167.973 inhabitants, respectively, according to IBGE (2018).

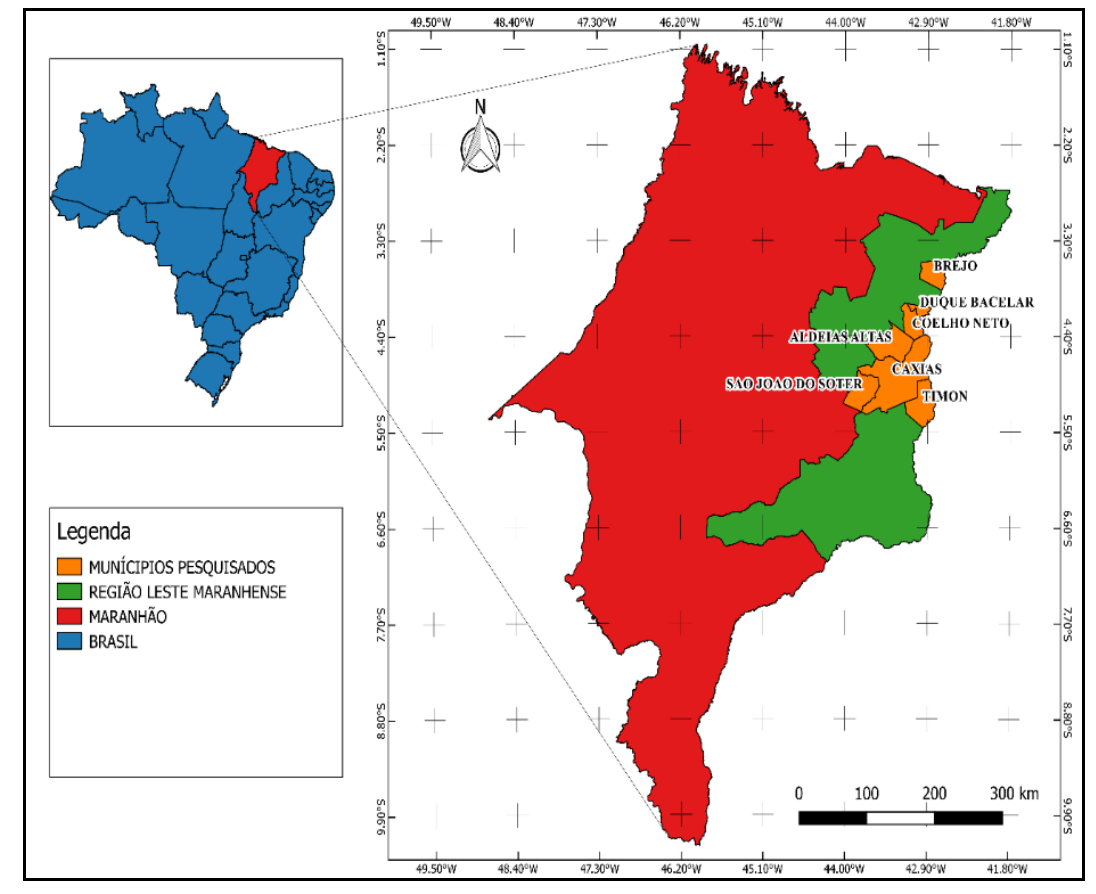

Figure 1. Location map of the municipalities where the questionnaires were carried out

All municipalities are located at the Maranhense East Mesoregion, consisting of 44 cities and covering $70.535 \mathrm{~km}^{2}$. According to the Köppen classification, this mesoregion belongs to the Aw climate zone, with a humid tropical climate, a mean temperature of $28^{\circ} \mathrm{C}$ and a mean annual rainfall of $1.700 \mathrm{~mm}$ (INMET, 2018).

The survey was carried out through direct interviews, conducted during office hours, with the owners or managers (store and/or fruits and vegetable sector) of the retail markets visited. It used a questionnaire elaborated according to Almeida et al. (2012a), containing objective questions that included information on socioeconomic aspects, disposal, packaging, storage, commercialization and postharvest losses of fruits.

This information allowed the definition of a socio-economic profile of the traders, a scenario for the sale of fruit and vegetables, and a diagnosis of postharvest losses in the municipalities studied. Regarding the monthly income from the sale of produce, it was based on minimum wages, which at the time of the study was quoted at $\mathrm{R} \$ 954.00$. 


\section{Al Macrothink}

The origin of postharvest losses was typified according to Chitarra and Chitarra (2005), in mechanical losses, physiological disorders and phytopathological injuries. The estimated postharvest losses, in percentage, was estimated by the following equation:

$$
\text { Losses }(\%)=\frac{\mathrm{VO}-\mathrm{WV}}{\mathrm{WV}} \times 100
$$

Where, VO referred to the mean amount of fruit/vegetable offered per week $\left(\mathrm{kg} \mathrm{week}^{-1}\right)$ and $\mathrm{VV}$ represented the average amount of fruit / vegetable sold per week $\left(\mathrm{kg} \mathrm{week}^{-1}\right)$. These relative losses were classified as low (less than or equal to 5\%), medium (among 5.1 and $10.0 \%$ ) and high (greater than or equal to $10.1 \%$ ), according to Tofanelli et al., (2009).

Through postharvest loss estimates in percent, for each fruit and vegetable marketed, it was possible to estimate the losses in kilograms on the volume offered per week. This provided a better highlight of the volume lost for each product, according to its importance in consumption and consequently in supply into commercial establishments.

Traders pointed out through objective questions, the main causes of injury, for each fruit and vegetable. To results quantification, the mean percentage of these causal agents was obtained for each fruit and vegetable, with subsequent calculation of the relative percentage of interference on the total percentage of postharvest losses.

Data were analyzed by descriptive statistics and showed in graphs and tables, according to the type of variable analyzed. Losses were expressed as percentage (\%) and kilograms per week $\left(\mathrm{kg} \mathrm{week}^{-1}\right)$, the mean loss of each fruit was associated with the relative percentage of causal factor performance. Thus, postharvest losses were referred to as physiological, mechanical and phytopathological losses.

Besides, the mean loss percentage of each fruit and vegetable, it was estimated the mean standard error and variation coefficient, aiming to define the experimental precision. The volume offered of fruit and vegetables was estimated as the quotient of the amount offered, in kilograms per week, of each fruit and vegetable, by the analyzed sample space (145 commercial establishments).

To make this study wider and more reliable, losses were estimated for each single municipality, with their respective insertion microregions and population (estimated by IBGE, 2018). The data obtained were tabulated and presented in tables, associating the losses of fruit and vegetables to the causal factor.

\section{Results and Discussion}

The results expressed that although the research was conducted in different cities, some similar characteristics were detected among them, mainly regarding the origin of the products.

Among the cities evaluated, none of them was self-sufficient in the production of fruit and vegetables. The supply comes from other states, such as Ceará state $(66 \%)$ and Piauí state 
(33\%), especially the cities of Tianguá and Teresina, respectively (Table 1).

Table 1. Socioeconomic profile of fruit and vegetable traders at seven municipalities of the Maranhense East mesoregion, Brazil

\begin{tabular}{|c|c|c|c|}
\hline Variables & Categories & $\begin{array}{c}\text { Frequency } \\
(n=145)\end{array}$ & $\%$ \\
\hline \multirow{7}{*}{ Education Level } & Not Literate & 15 & $10.34 \%$ \\
\hline & Incomplete Elementary School & 64 & $44.13 \%$ \\
\hline & Complete Primary Education & 38 & $26.20 \%$ \\
\hline & Incomplete High School & 18 & $12.41 \%$ \\
\hline & Complete High School & 9 & $6.20 \%$ \\
\hline & Incomplete Higher Education & 0 & $0 \%$ \\
\hline & Complete Higher Education & 1 & $0.68 \%$ \\
\hline \multirow{3}{*}{$\begin{array}{c}\text { Technical Knowledge in } \\
\text { Production }\end{array}$} & High & 18 & $12.41 \%$ \\
\hline & Medium & 80 & $55.17 \%$ \\
\hline & Low & 47 & $32.41 \%$ \\
\hline \multirow{3}{*}{$\begin{array}{l}\text { Technical Knowledge in } \\
\text { Management }\end{array}$} & High & 0 & $0 \%$ \\
\hline & Medium & 116 & $80.00 \%$ \\
\hline & Low & 29 & $20.00 \%$ \\
\hline \multirow{3}{*}{$\begin{array}{l}\text { Technical Knowledge in } \\
\text { Marketing }\end{array}$} & High & 22 & $15.17 \%$ \\
\hline & Medium & 90 & $62.06 \%$ \\
\hline & Low & 33 & $22.75 \%$ \\
\hline \multirow{2}{*}{$\begin{array}{l}\text { Interest in Training } \\
\text { Courses }\end{array}$} & Yes & 93 & $64.13 \%$ \\
\hline & No & 52 & $35.86 \%$ \\
\hline \multirow{2}{*}{ Cooling use } & Yes & 60 & $41.37 \%$ \\
\hline & No & 85 & $58.62 \%$ \\
\hline \multirow{3}{*}{ Transport } & Canvas-covered Trucks & 124 & $85.51 \%$ \\
\hline & Open truck without canvas & 12 & $8.27 \%$ \\
\hline & Box truck & 9 & $6.20 \%$ \\
\hline \multirow{4}{*}{ Supplies } & Ceará & 95 & $65.51 \%$ \\
\hline & Piauí & 48 & $33.10 \%$ \\
\hline & Bahia & 1 & $0.68 \%$ \\
\hline & Pernambuco & 1 & $0.68 \%$ \\
\hline
\end{tabular}

These results corroborate those obtained by Tomm et al. (2018) to six cities of the Chapadinha Microregion (MA) and indicates that the productive deficiency of fruit and vegetable at the East Maranhense mesoregion is a problem to be solved.

It was observed that the closer to State Supply Centers (CEASA) of Teresina (PI), the greater 
the participation of this trading post in the origin of the products. While in the cities farthest from these supply centers, there is greater importance of fruit and vegetables from Ceará, with some collaboration from Bahia and/or Pernambuco (Juazeiro-BA and Petrolina-PE, respectively). According to Ferreira (2019), the greater the distance from the producer/distributor center to the trading/consumption center, the shorter the shelf life of fruit and vegetable, particularly when efficient conservation technologies are not used.

The low educational level (incomplete high school) and a medium level of knowledge in agricultural production, management and marketing are facts that also coincide in all retail markets. However, it is important to highlight that most traders (64\%) showed interest in training courses (Table 1). According to Alcantara (2005), school education is an important factor in the development of the production process, particularly at work dealing.

According to Alcantara (2005), school education is an important factor in the development of the production process, particularly at work dealing. Usually, higher-skilled people are better prepared for problem-solving and more receptive to greater awareness of how to achieve satisfactory marketing results. Therefore, training of traders in good postharvest practices and business management may be an efficient strategy to increase profitability in marketing perishable products such as fruits and vegetables.

As traders' reports, there is no attention to standardization and the use of appropriate containers for fruit and vegetables packing according to their different classifications. The use of refrigeration when present, in $41 \%$ of cases, was restricted only to temperate and subtropical fruits, such as apple, pear, grape, and plum, or to product conservation from other segments, such as lactic drinks and soft drinks (Table 1).

The transport is carried out, mostly, (86\%) through canvas-covered trucks. With a few exceptions in uncooled Box truck (8\%) and open truck without canvas (6\%) (Table 1). The runways are all paved, but are not in perfect traffic conditions, having complaints about the presence of holes in all cities surveyed.

Table 2 shows the volume offered, the magnitude of vegetable losses and their main causes. The following decreasing order of post-harvest vegetable losses was obtained: sweet pepper $(16.42 \pm 2.21 \%)>$ lettuce $(11.79 \pm 0.42 \%)>$ tomato $(11.38 \pm 4.04 \%)>$ eggplant $(11.09 \pm$ $0.99 \%)>$ sweet potato $(11.03 \pm 0.77 \%)>$ cucumber $(10.84 \pm 1.85 \%)>\operatorname{carrot}(8.91 \pm$ $0.74 \%)>$ potato $(8.38 \pm 1.03 \%)>$ coriander $(7.47 \pm 2.33 \%)$. The coefficient of variation ranged from 3.02 to $15.97 \%$ and indicated good experimental precision in the survey.

Estimated losses for peppers, lettuce, tomatoes, eggplants, sweet potatoes, and cucumbers were classified as high, while for carrots, potatoes and coriander were median. In general, the major causes of losses were physiological, which ranged from $7.47 \%$ (coriander) to $14.75 \%$ (bell pepper). 


\section{Mll Macrothink}

Journal of Agricultural Studies

ISSN 2166-0379

2020, Vol. 8, No. 3

Table 2. Estimation of postharvest losses of vegetables in seven cities in the Maranhense East mesoregion, Brazil

\begin{tabular}{|c|c|c|c|c|c|c|c|c|}
\hline \multirow{2}{*}{ Vegetable } & \multirow{2}{*}{ VTO } & \multirow{2}{*}{ VMO } & \multirow{2}{*}{ PMT } & \multicolumn{5}{|c|}{--- Causes $(\%)$--- } \\
\hline & & & & $\mathrm{PRT} \pm \mathrm{e}$ & PFS & PFT & $\mathrm{PM}$ & $\mathrm{CV}$ \\
\hline Bell Pepper & 4,095 & 34.71 & 5.69 & $16.42 \pm 2.21$ & 14.75 & 0.97 & 0.70 & 6.08 \\
\hline Lettuce* & 2,208 & 16.54 & 1.95 & $11.79 \pm 0.42$ & 11.79 & 0.00 & 0.00 & 3.02 \\
\hline Tomato & 10,955 & 94.01 & 10.69 & $11.38 \pm 4.04$ & 10.55 & 0.19 & 0.65 & 6.05 \\
\hline Eggplant & 1,135 & 22.62 & 2.50 & $11.09 \pm 0.99$ & 10.36 & 0.00 & 0.74 & 15.97 \\
\hline Sweet potato & 4,199 & 28.53 & 3.14 & $11.03 \pm 0.77$ & 10.58 & 0.00 & 0.44 & 3.92 \\
\hline Cucumber & 4,630 & 38.49 & 4.17 & $10.84 \pm 1.85$ & 10.28 & 0.42 & 0.14 & 7.26 \\
\hline Carrot & 4,425 & 35.03 & 3.12 & $8.91 \pm 0.74$ & 8.12 & 0.20 & 0.58 & 4.23 \\
\hline Potato & 6,665 & 48.62 & 4.07 & $8.38 \pm 1.03$ & 7.91 & 0.00 & 0.47 & 4.48 \\
\hline Coriander* & 10,240 & 85.01 & 6.35 & $7.47 \pm 2.33$ & 7.47 & 0.00 & 0.00 & 5.89 \\
\hline
\end{tabular}

VTO $=$ Total Volume Offered, in $\mathrm{kg}$ week $^{-1} ; \mathrm{VMO}=$ Average Volume Offered, in kg week ${ }^{-1}$; PMT = Total Average Losses, in kg week ${ }^{-1} ;$ PRT = Total Relative Loss, in (\%); * - volume sold in units per week; PFS = Physiological Losses; PFT = Phytopathological Losses; PM = Mechanical Losses; CV = Coefficient of Variation (\%); e $= \pm$ Mean Standard Error (\%).

The average marketed volume of peppers was $34.71 \mathrm{~kg}^{\text {week }}{ }^{1}$, with estimated losses of $16.42 \pm 2.21 \%$. Of these, $14.75 \%$ were physiological withering (Table 2). According to Almeida et al. (2012b), withering causes wrinkling of the pepper epidermis and reduces its commercial acceptance. This result was superior to those found by Tomm et al. (2018) and Sousa et al. (2018), in similar research carried out in Maranhão.

Tomm et al. (2018) estimated an average loss of $10.13 \pm 0.07 \%$ for 65 retail markets of fruit and vegetable at the Chapadinha microregion (Anapurus, Belagua, Chapadinha, Mata Roma, São Benedito and Urbano Santos), while Sousa et al. (2018) detected $11.98 \pm 0.42 \%$ for 20 retail markets in the city of Chapadinha (MA).

On the other hand, Almeida et al. (2012) quantified an average loss of $20.28 \%$ for the marketing of this vegetable in 87 retail markets of Areia (PB). Although the estimates are different, it is important to highlight that the physiological causes were the most expressive in the four studies. Tomm et al. (2018) and Sousa et al. (2018) reported participation of 62.69 to 
94.99\% of physiological disorders in the average losses of peppers, whereas in the present study, an estimate of $89.83 \%$ was obtained. This demonstrates that the long-time until market may interfere om the shelf life of peppers.

To lettuce, the mean offered was 16.54 units per week, with total average losses of $11.79 \%$, resulting only from physiological disorders. This result was lower than the $14.58 \%$ obtained by Almeida et al. (2012 b) at the Areia street market (PB), whose average volume offered was 51 lettuce units. However, it was higher than the $9.73 \pm 1.10 \%$ estimated by Figueirinha (2019) in five municipalities of Maranhão, inserted in three distinct microregions. Both authors also obtained predominance of physiological causes, associated with losses/losses.

These results corroborate with Chitarra and Chitarra (2005), who pointed out physiological disorders as the main causes of lettuce losses. Henrique et al. (2012) signalized that lettuce has a limited useful life due to its fragile physical constitution, sensitive to injuries and dehydration, when not properly preserved. Therefore, it is thought that the commercialization conditions, the sales interval and the scarcity of conservation techniques contributed to the estimates of lettuce losses in the present survey.

Tomato showed an average offered volume of $94.01 \mathrm{~kg}^{-1} \mathrm{wek}^{-1}$, which was lower than estimated by Tomm et al. (2018) in six municipalities of the Chapadinha Microregion (MA), $128.20 \mathrm{~kg} \mathrm{week}^{-1}$; Sousa et al. (2018) in the city of Chapadinha (MA), $226.50 \mathrm{~kg} \mathrm{week}^{-1}$; and Figueirinha (2019) in five municipalities of Maranhão, inserted in different microregions, $534.21 \mathrm{~kg} \mathrm{week}^{-1}$. According to Tarabay et al. (2018), the planning of the offered volume may help to reduce postharvest losses, by providing shorter shelf exposure time.

The average losses were estimated at $11.38 \%$, which were caused by physiological disorders $(10.55 \%)$, mostly. In conformity with the statements of Tarabay et al. (2018), the lower volume offered resulted in reduction of losses, compared to surveys conducted by Tomm et al. (2018), Sousa et al. (2018) and Figueirinha (2019), who estimated relative losses of 18.38; 14.11 and $21.24 \%$, respectively, for other municipalities of Maranhão.

Although the estimated losses for tomatoes were lower than those estimated in other municipalities of Maranhão, it is important to note that they were classified as high and reinforce the alert about the marketing of fruit and vegetables in Maranhão. It is understood that there is a need for incentives to expand the vegetable production chain in different Maranhão microregions, given that the distance traveled between the production/distribution centers and the marketing/consumption centers may be favoring the increase of postharvest losses, especially in fruit and leafy vegetables such as peppers, tomatoes, and lettuce.

Table 3 shows the magnitude of postharvest losses of fruits marketed in Aldeias Altas, Brejo, Caxias, Coelho Neto, Duke Bacelar, São João do Sóter and Timon (MA). The decreasing order of postharvest losses were: plum $(35.65 \pm 1.34 \%)>$ papaya $(17.93 \pm 3.79 \%)>$ guava $(15.63 \pm 2.79 \%)>$ avocado $(11.02 \pm 1.47 \%)>\operatorname{mango}(10.06 \pm 1.7 \%)>$ pear $(9.17 \pm$ $1.54 \%)>$ pineapple $(9.06 \pm 2.73 \%)>$ banana $(8.14 \pm 5.12 \%)>$ apple $(7.73 \pm 1.45 \%)>$ grapes $(7.69 \pm 1.55 \%)>$ watermelon $(6.93 \pm 5.74 \%)>$ passion fruit $(6.56 \pm 1,59 \%)>$ melon $(6.03 \pm$ $0.90 \%)$. 
Similar to that pointed to vegetables, physiological disorders were the main causal factor occurring in fruits, whose estimates ranged from $5.87 \%$ (melon) to $35.65 \%$ (plum). The coefficient of variation ranged from $5.88 \%$ to $42.44 \%$ and indicates good experimental accuracy for a field survey. However, it is important to emphasize that the highest estimated coefficients of variation for pear and plum may be associated with the fact that they are fruits not marketed by all traders interviewed, which induces greater data discrepancy effects on the calculation of experimental error.

Table 3. Estimation of postharvest fruit losses in Aldeias Altas, Brejo, Coelho Neto, Caxias, Duke Bacelar, São João do Sóter and Timon, Maranhão, Brazil

$(\%)$

\begin{tabular}{|c|c|c|c|c|c|c|c|c|c|c|}
\hline Fruits & VTO & VMO & VMC & PMT & $\mathrm{PT} \pm \mathrm{e}$ & PFS & PFT & PM & PB & $\mathrm{CV}$ \\
\hline Plum & 80,00 & 11.43 & 8.21 & 2.92 & $35.65 \pm 1.34$ & 35.65 & 0.00 & 0.00 & 0.00 & 38.01 \\
\hline Papaya & 6,465 & 923.57 & 48.84 & 8.75 & $17.93 \pm 3.79$ & 16.79 & 0.23 & 0.91 & 0.00 & 7.09 \\
\hline Guava & 2,903 & 414.71 & 35.38 & 5.52 & $15.63 \pm 2.79$ & 15.12 & 0.09 & 0.41 & 0.00 & 14.15 \\
\hline Avocado & 3,765 & 537.86 & 37.95 & 4.18 & $11.02 \pm 1.47$ & 8.69 & 0.50 & 1.83 & 0.00 & 8.32 \\
\hline Mango & 4,601 & 657.29 & 43.57 & 4.38 & $10.06 \pm 1.76$ & 9.83 & 0.08 & 0.15 & 0.00 & 7.78 \\
\hline Wait & 106.00 & 106.00 & 19.22 & 1.76 & $9.17 \pm 1.54$ & 9.14 & 0.00 & 0.03 & 0.00 & 42.44 \\
\hline Pineapple & 7,475 & 1067.86 & 61.37 & 5.56 & $9.06 \pm 2.73$ & 9.00 & 0.00 & 0.06 & 0.01 & 8.03 \\
\hline Banana & 17,990 & 2570.00 & 165.46 & 13.46 & $8.14 \pm 5.12$ & 7.53 & 0.22 & 0.16 & 0.00 & 7.42 \\
\hline Apple & 4,701 & 671.57 & 43.97 & 3.39 & $7.73 \pm 1.45$ & 7.50 & 0.00 & 0.22 & 0.00 & 7.94 \\
\hline Grape & 4,490 & 641.43 & 52.24 & 4.01 & $7.69 \pm 1.55$ & 6.62 & 0.20 & 0.88 & 0.00 & 8.39 \\
\hline Watermelon & 22,105 & 3157.86 & 182.05 & 12.61 & $6.93 \pm 5.74$ & 6.89 & 0.00 & 0.04 & 0.00 & 6.87 \\
\hline Passion fruit & 6,087 & 869.57 & 54.82 & 3.59 & $6.56 \pm 1.59$ & 6.30 & 0.09 & 0.17 & 0.00 & 8.15 \\
\hline Melon & 5,081 & 725.86 & 40.10 & 2.41 & $6.03 \pm 0.90$ & 5.87 & 0.00 & 0.12 & 0.04 & 5.88 \\
\hline
\end{tabular}

VTO = Total Volume Offered, in kg week ${ }^{-1} ; \mathrm{VMO}=$ Average Volume Offered, in kg week ${ }^{-1}$; PMT = Total Average Losses, in kg week ${ }^{-1}$; PRT = Total Relative Loss, in (\%); * - volume sold in units per week; PFS = Physiological Losses; PFT = Phytopathological Losses; PM = 
Mechanical Losses; CV = Coefficient of Variation (\%); e = \pm Mean Standard Error (\%).

Plum showed $35.65 \%$ of postharvest losses, compared to a small average offered volume of $8.21 \mathrm{~kg}$ per week. With an emphasis on the physiological disorders that presented causal totality. Among the studied vegetables, the plum obtained the highest estimate of postharvest losses, which may be associated with the fact that it is a temperate fruit, highly perishable and demanding in conservation technologies, such as the refrigerated system. Stanger et al. (2014) add that as it is a climacteric fruit, the plum has a high metabolic rate during ripening and it is common to occur pulp darkening, when not properly preserved.

According to Pio (2018), temperate fruits such as plum require low temperatures $(0.0$ to $0.5{ }^{\circ} \mathrm{C}$ ) to increase shelf life. However, the relative humidity must not be less than $90 \%$. This, under the studied marketing conditions, it is only possible through the use of refrigeration, which is a storage technology that is difficult for merchants to access, either at initial cost or maintenance costs.

In general, it was observed that when not absent ( $41 \%$ of cases), refrigeration was misused by freezers or refrigerators, which usually have a relative humidity of less than $60 \%$. In combination with the long-distance travel to the final marketing/consumption, long shelf life, expressive prices practiced, resulted in drastic estimated losses for plum (35.65 $\pm 1.34 \%)$, in this survey.

Accordingly, Prusky et al. (2015) in addition to the cooling, careful handling of the fruit is a very important process and involves several steps, such as effective supervision, careful transportation, gentle handling, and reduced fingertip contact. This may help in maintaining the characteristics of fruits for a longer period of time, but unfortunately is not a common practice in the marketing of plum and other fruits in Maranhão.

The estimated loss for plum was higher than the $20.33 \%$ estimated by Tomm et al. (2016) in the city of Chapadinha (MA); $27.10 \%$ obtained by Cristofoli et al. (2014) in Fortaleza (CE), and $14.70 \%$ found by Tofanelli et al. (2009) in Mineiros (GO). Therefore, it is understood that the most aggravating factor is the small size of some municipalities analyzed in the present study, such as Duque Bacelar (11,296 inhabitants) and São João do Sóter (18,438 inhabitants), whose average sales volume was also low, estimated at $8.21 \mathrm{~kg}$ per week. This reflects the adoption of mistaken practices in the plum commercialization in municipalities of East Maranhense.

The volume offered by plum was around twenty times lower than the volume offered by watermelon and banana, which had losses four times smaller. That is, the conservation technologies and prices practiced may be leading to increased losses of this fruit, although there is adequate planning of the offered volume.

This hypothesis corroborates Tomm et al. (2016), which reported low intention to purchase plum in Chapadinha (MA), mainly due to its expressive commercialization price, which in some markets reached $\mathrm{R} \$ 15.00$ per kilogram in 2016. Tofanelli et al. (2009) corroborated that one of the main consequences of losses to society is the high prices charged. Including recurring losses from losses. 
In relation to papaya, the average volume traded per week was $48.84 \mathrm{~kg}$ per establishment, with estimated losses of $17.93 \%$, mostly caused by physiological disorders (93.64\%). This relative loss was higher than the $11.64 \%$ estimated by Silva (2017) in five municipalities of the Chapadinha Microregion (MA); $11.31 \%$ quantified by Cavalcante et al. (2011) at CEASA de Campina Grande (PB), and 7.20\% estimated by Tofanelli et al. (2009), in Mineiros (GO). However, both results were lower than those estimated by Nascimento et al. (2016) in the city of Chapadinha (MA), for both papaya 'Formosa' (22.80\%) and papaya 'Hawaii' $(35.80 \%)$.

According to Godoy et al. (2010), papaya is highly perishable in the postharvest phase and has higher loss rates among tropical fruit, usually due to microbiological contamination, physiological disorders, mechanical damage, excessive ripening, improper handling and loss of structural integrity. In the same way, Silva et al. (2018) affirmed, physiological disorders in papaya may be related to non-observance of the ideal harvesting point, which may influence early discard due to excessive ripening.

Silva et al. (2018) found $10.62 \%$ of losses due to physiological disorders, for a total of $11.64 \%$ of postharvest losses, at the markets in five municipalities of the Chapadinha Microregion. These results were proportional to those obtained in the present study, as $93.54 \%$ of the relative losses originated from physiological causes.

Guava presented average volume offered of $35.38 \mathrm{~kg}$ per week, with average losses of $15.63 \%$. Of these, $96.74 \%$ came from physiological causes, probably due to poor conditions of conservation and marketing of the fruit. This result can be explained by Velho et al. (2011), who emphasized that because it is a climacteric fruit, guava has a high respiratory rate when stored at temperatures above $20^{\circ} \mathrm{C}$.

In this aspect, El-Ramady et al. (2015) reinforce that the high temperatures associated with improper transport, handling and packaging, culminate in rapid fruit ripening and softening. These are characteristics rejected by the consumer market and provide increased postharvest losses, which in the present study were estimated at $15.63 \pm 2.79$ and classified as high.

Table 4 shows the loss of vegetables and fruits in average values for each city studied. It was observed that the highest average offered volumes of fruits and vegetables were estimated for the city of Timon (MA). This is probably due to the fact that this city has a trading post (CEASA), whose supply of products comes from distribution centers or producers of Teresina (PI) and metropolitan cities. 
Table 4. Postharvest losses of fruit and vegetables in the retail Aldeias Altas, Brejo, Caxias, Grandson Rabbit, Duke Bacellar, St. John of the Soter and Timon (MA)

\begin{tabular}{cccccccccc}
\hline & & & & & & & & & \\
Cities & Pop. & N & VM & PMT & PRT \pm e & VM & PMT & PRT \pm e \\
\hline Aldeias Altas & 26,387 & 21 & 464.44 & 22.44 & $4.83 \pm 3.12$ & 436.15 & 20.73 & $4.75 \pm 4.64$ \\
Brejo & 36,139 & 08 & 201.44 & 21.61 & $10.73 \pm 7.46$ & 215.69 & 24.31 & $11.27 \pm 15.73$ \\
Coelho Neto & 49,246 & 19 & 1051.67 & 187.00 & $17.78 \pm 33.97$ & 1574.38 & 180.77 & $11.48 \pm 33.22$ \\
Caxias & 164,224 & 40 & 1278.33 & 69.28 & $5.42 \pm 4.69$ & 1460.75 & 70.79 & $4.85 \pm 5.97$ \\
Duque Bacelar & 11,296 & 11 & 412.22 & 24.78 & $6.01 \pm 4.74$ & 496.15 & 19.71 & $3.97 \pm 4.50$ \\
São João do Sóter & 18,438 & 28 & 837.22 & 31.00 & $3.70 \pm 2.29$ & 709.23 & 23.67 & $3.34 \pm 2.76$ \\
Timon & 167.973 & 18 & 1149.33 & 154.67 & $13.46 \pm 28.75$ & 1872.69 & 202.92 & $10.84 \pm 48.38$ \\
\hline
\end{tabular}

Pop. = Population of the municipality, in number of inhabitants; $\mathrm{N}=$ Number of establishments sampled; $\mathrm{MV}=$ Average total volume traded, in $\mathrm{kg}$ week ${ }^{1}$; $\mathrm{PMT}=$ Total average losses per establishment in $\mathrm{kg}_{\text {week }}{ }^{1}$; PRT $=$ Total relative losses, in percentage (\%); $\mathrm{e}= \pm$ standard error of the mean $(\%)$.

Regarding post-harvest losses for vegetables, the most important were means over $10.10 \%$ (high losses), registered in the municipalities of Coelho Neto (17.78\%), Timon (13.46\%) and Brejo (10.73\%). While for fruits, the largest losses were recorded for Coelho Neto $(11.48 \%)$, Brejo (11.27\%) and Timon (10.84\%). Therefore, these three municipalities only oscillated in the ranking between losses of vegetables and fruits and stood out in relation to the others. Which may be contributing to the decrease in profits and the increase of environmental impacts caused by the increase of the urban waste volume.

Comparing the losses with the volumes offered, it was found that Timon and Coelho Neto municipalities were among the three municipalities that offered the most and lost the most fruits in the postharvest stage. These results corroborate with Tofanelli et al. (2009), who pointed out that the increase in the volume of vegetables offered may contribute to greater losses in retail, due to their high perishability.

It is important to emphasize that the data obtained for Coelho Neto are more alarming than Timon because its population is equivalent to one-third of this municipality. Given this, the volume offered seems to be incompatible with demand, given that even with a population well below Timon, the supply of fruits and vegetables in Coelho Neto is equivalent. With consequent high losses for vegetables (17.78\%) and fruits (11.78\%). 
Therefore, it is valid to make traders aware of the proper management of the volume offered, as well as the adoption of practices that increase conservation, particularly in Coelho Neto. Another city that expressed warning about losses was Brejo, whose population and volumes offered are low, but the losses were high. Possibly this is due to the postharvest practices employed for the conservation and marketing of fruits and vegetables.

To sum, the survey results indicated that losses are caused by ignorance of good post-harvest practices associated with adverse environmental conditions, unfavorable highways and poor knowledge of commercial management. Nevertheless, most traders are interested in capacity building, demonstrating recognition of the need and willingness to reduce losses. Therefore, this would be the ideal point for intervention.

Several studies focus on the significant estimate of postharvest losses in Brazil, especially in the municipalities of Maranhão that still have the aggravating low Human Development Index (HDI). Thus, it is understood that to improve the income and employment conditions associated with the fruit and vegetable segment, it is necessary to optimize the processes of training, awareness and incentive to local production.

\section{Conclusion}

Traders predominantly have only elementary school or incomplete high school (92\%) and medium technical knowledge about production, management, and marketing on fruit and vegetable. The fruits and vegetables come from other states, such as Piauí, Bahia and Ceará, and are drained through canvas-covered trucks $(86 \%)$. The three vegetables with the highest loss estimates were bell pepper $(16.42 \pm 2.21 \%)$, lettuce $(11.79 \pm 0.42)$ and tomato $(11.38 \pm$ $0.19 \%)$. whereas, for fruits, the highest loss estimates were plum $(35.65 \pm 1.34 \%)$, papaya $(17.93 \pm 3.79 \%)$ and guava $(15.63 \pm 2.79 \%)$. Among the causes, those of physiological order was the most important. To the cities, the largest losses of vegetables occurred in Coelho Neto (17.78\%), Timon (13.46\%) and Brejo (10.73\%). Regarding fruits, the order was Coelho Neto (11.48\%), Brejo (11.27\%) and Timon (10.84\%). There is a need for better training and awareness of traders regarding the adoption of good post-harvest practices and proper management of the commercial activity, as a way to increase the profitability of this activity, which on average generates two minimum wages per month.

\section{Acknowledgment}

The Foundation for the Support of Research and Scientific and Technological Development of Maranhão state (FAPEMA) for the financial support in the Edital Universal 31/2016, process $960 / 17$, and for the granting of the first author's scholarship for scientific initiation.

\section{References}

Alcantara, J. S. (2005). Educação profissional e qualificação do trabalhador: o caso do curso técnico em Telecomunicações do SENAI de Uberlândia. (Dissertação de mestrado), Universidade Federal de Uberlândia, Uberlândia.

Almeida, E. I. B., Lucena, H. H., Ribeiro, W. S., Oliveira, M. R. T., \& Barbosa, J. A. (2012b). Análise das perdas de caule, folhas e frutos de hortaliças frescas comercializadas na rede 
varejista de Areia (PB). Revista Brasileira de Agropecuária Sustentável, 2(2), 81-9. https://doi.org/10.21206/rbas.v2i2.170

Almeida, E. I. B., Lucena, H. H., Ribeiro, W. S., Oliveira, M. R. T., \& Barbosa, J. A. (2012). Análise das perdas de caule, folhas e frutos de hortaliças frescas comercializadas na rede varejista de Areia (PB). Revista Brasileira de Agropecuária Sustentável, 2(2), 81-9.

Almeida, E. I. B., Ribeiro, W. S., Costa, L. C., Lucena, H. H., \& Barbosa, J. A. (2012a). Levantamento de perdas em hortaliças frescas na rede varejista de Areia (PB). Revista Brasileira de Agropecuária Sustentável, 2(1), 53-60.

Cavalcanti, L. A., Carmo Junior, T. R., Pereira, L. A., Asano, R. Y., Garcia, M. C. L., Cardeal, C. M., \& França, N. M. (2011). Efeitos de uma intervenção em escolares do ensino fundamental I, para a promoção de hábitos alimentares saudáveis. R. bras. Ci. e Mov, 20(2), 5-13. http://dx.doi.org/10.18511/rbcm.v20i2.2408

Cenci, S. A. (2006). Boas Práticas de Pós-colheita de Frutas e Hortaliças na Agricultura Familiar. In: NASCIMENTO NETO F. (Org.). Recomendações Básicas para a Aplicação das Boas Práticas Agropecuárias e de Fabricação na Agricultura Familiar. (1ª ed.). Brasília: Embrapa Informação Tecnológica. p. 67-80.

Chitarra, M. I. F., \& Chitarra, A. B. (2005). Pós-colheita de frutos e hortaliças: fisiologia e manuseio. ( $2^{\mathrm{a}}$ ed.). Revisada e ampliada. Lavras: UFLA. p. 785.

Cristofoli, D., Markovic, J., \& Meneguzzo, M. (2014). Governança, gerenciamento e desempenho em redes públicas: como obter sucesso em redes de governança compartilhada. Journal of Management \& Governance, 18(1), 77-93. https://doi.org/10.1007/s10997-012-9237-2

Durigan, J. F. (2013). Pós colheita de frutas. Revista Brasileira de Fruticultura, Jaboticabal, 35(2), 339-675. https://doi.org/10.1590/S0100-29452013000200001

El-Ramady, H. R., Domokos-Szabolcsv, É., Abdalla, N. A., \& Hussein, S. (2015). Gerenciamento pós-colheita do armazenamento de frutas e legumes. Revista de agricultura sustentável, 1, 65-152. https://doi.org/10.1007/978-3-319-09132-7-2

Ferreira, L. S. (2019). Perdas pós-colheita de hortifrútis, em sete municípios maranhenses, inseridos em diferentes microrregiões. (Monografia), Universidade Federal do Maranhão, Chapadinha (Maranhão).

Figueirinha, K. T. (2019). Levantamento de perdas de hortifrútis em cinco municípios maranhenses, inseridos em diferentes microrregiões. (Monografia), Universidade Federal do Maranhão, Chapadinha (Maranhão).

Godoy, A. E., Jacomino, A. P., Cerqueira-Pereira, E. C., Gutierrez, A. S. D., Vieira, C. E. M., \& Forato, L. A. (2010). Injúrias mecânicas e seus efeitos na qualidade de Mamões Golden. Revista Brasileira de Fruticultura, 32(3), 682-691. https://doi.org/10.1590/s0100-29452010005000086 
Guerra, A. M. N., Costa, A. C. M., Ferreira, J. B. A., Tavares, P. R. F., Vieira, T. S., \& Medeiros, A. C. (2017). Avaliação das principais causas de perdas pós-colheita de hortaliças comercializadas em Santarém, Pará. Revista Verde de Agroecologia e Desenvolvimento Sustentável, 12(1), 34-40. https://doi.org/10.18378/rvads.v12i1.4809

Henrique, C. M., Parisi, M. C. M., \& Prati, P. (2012). Pós-colheita de Alface. APTA Regional. Pesquisa \& Tecnologia, 9(2), 4-6.

Hoek, A. C., Pearson, D., James, S.W., Lawrence, M. A., \& Friel, S. (2017). Healthy and environmentally sustainable food choices: Consumer responses to point-of-purchase actions. Food quality and preference, 58, 94-106. https://doi.org/10.1016/j.foodqual.2016.12.008

Horticultura Maranhão, Sebrae. (2009). [Online] Disponível: www.sebrae-ma.gov.br/Horticultura (24 de abril de 2019).

IBGE - Instituto Brasileiro de Geografia e Estatística. Censo demográfico (2018). [Online] Disponível: https://cidades.ibge.gov.br>brasil (27 de setembro de 2019).

INMET - Instituto Nacional de Metereologia. Ministério da Agricultura, Pecuária e Abastecimento. (2018). [Online] Disponível: http://www.inmet.gov.br/portal/index.php?r=clima/mesTempo (06 de julho de 2019).

Jaime, P. C., Figueiredo, I. C. R., Moura, E. C., \& Malta, D. C. (2009). Fatores associados ao consumo de frutas e hortaliças no Brasil, 2006. Revista de Saúde Pública, 43(2), 57-64. https://doi.org/10.1590/s0034-89102009000900008

Köppen, W., \& Geiger, R. (2019). Klimate der Erde. Gotha: Verlag Justus Perthes. Wall-map $150 \mathrm{~cm}$ x $200 \mathrm{~cm}, 1928$.

Nascimento, S. S., Mendes, M. S., Sousa, A. N. S., Tomm, T. F. R., Almeida, E. I. B., \& Gondim, M. M. S. (2016). Levantamento de perdas pós-colheita de frutas tropicais em Chapadinha (MA). In: Farias, M. F. et al. (Org.). Tópicos em produção agrícola no Leste Maranhense. ( $1^{\mathrm{a}}$ ed.). São Luís: EDUFMA. p. 216-224.

Neves, L. C. (2016). Manual pós-colheita da fruticultura brasileira. ( $1^{\mathrm{a}}$ ed.). Londrina: Editora EDUEL. p. 494.

Pio, R. (2018). Cultivo de Fruteiras de Clima Temperado em Regiões Subtropicais e Tropicais. (2a ed.). Lavras: UFLA. p. 681.

Prusky, D., \& Keen, N. T. (2015). Involvemente of preformed antifungal compounds in the resistance of subtropical fruits to fungal decay. Plant Disease, 77(2), 114-119. https://doi.org/10.1094/pd-77-0114

Silva, L. R. (2017). Perdas pós-colheita de frutas na microrregião de Chapadinha, Maranhão-Brasil. (Monografia), Universidade Federal do Maranhão, Chapadinha (Maranhão).

Silva, L. R., Almeida, E. I. B., Ferreira, L. S., Figueirinha, K. T., Ferreira, A. G. C., \& Sousa, W. S. (2018). Estimates and causes of fresh fruit post-harvest losses in the Chapadinha 
Microregion, Maranhão, Brazil. Revista Agro@mbiente On-line, 12(4), 288-299. https://doi.org/10.18227/1982-8470ragro.v12i4.5223

Sousa, A. N. S., Almeida, E. I. B., Nascimento, S. S., Mendes, M. S., Sousa, W. S., \& Melo, P. A. F. R. (2018). Perdas pós-colheita de hortaliças no mercado varejista de Chapadinha,

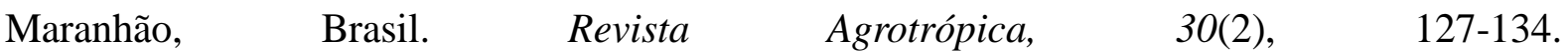
https://doi.org/10.21757/0103-3816.2018v30n2p127-134

Stanger, M. C., Steffens, C. A., Amarante, C. V. T., Corrêa, T. R., \& Tanaka, H. (2014). Qualidade pós-colheita de ameixas 'Camila' e 'Laetitia' colhidas em diferentes estágios de maturação. Revista Caatinga, 27(2), 214-221.

Tarabaya, P. A., Chahine-Tsouvalakisb, H., Tawkc, S. T., Nemer, N., \& Habib, W. (2018). Reduction of food losses in Lebanese apple through good harvesting and postharvest practices. Annals of Agricultural Sciences, 63(2), 207-213. https://doi.org/10.1016/j.aoas.2018.11.006

Tofanelli, M. B. D., Fernandes, M. S., Carrijo, N. S., \& Martins Filho, O. B. (2009). Levantamento de perdas em hortaliças frescas na rede varejista de Mineiros. Revista Horticultura Brasileira, 27(1), 116-120. https://doi.org/10.1590/s0102-05362009000100024

Tomm, T. F. R., Almeida, E. I. B., Figueirinha, K. T., Ferreira, L. S., Amorim, D. J., \& Gondim, M. M. S. (2018). Procedência e perdas pós-colheita de hortaliças na microrregião de Chapadinha, Maranhão, Brasil. Revista Agro@mbiente On-line, 12(3), 200-212. https://doi.org/10.18227/1982-8470ragro.v12i3.5026

Tomm, T. F. R., Sousa, A. N. S., Nascimento, S. S., Mendes, M. S., Almeida, E. I. B., \& Gondim, M. M. S. (2016). Cenário da comercialização e estimativa de perdas pós-colheita de frutas temperadas em Chapadinha (MA). In: Farias, M. F. et al. (Org.). Tópicos em produção agrícola no Leste Maranhense. (1ª ed.). São Luís: EDUFMA. p. 232-240.

Velho, A. C., Amarante, C. V. T., Argenta, L. C., \& Steffens, C. A. (2011). Influência da temperatura de armazenamento na qualidade pós-colheita de goiabas serranas. Revista Brasileira de Fruticultura, 33(1), 14-20. https://doi.org/10.1590/s0100-29452011005000016

\section{Copyright Disclaimer}

Copyright for this article is retained by the author(s), with first publication rights granted to the journal.

This is an open-access article distributed under the terms and conditions of the Creative Commons Attribution license (http://creativecommons.org/licenses/by/4.0/). 